\title{
Whither African Development? A Preparatory for an African Alternative Reformulation of the Concept of Development
}

\author{
Zubairu Wai*
}

\begin{abstract}
Intended as a preparatory for an African alternative reformulation of the concept of development, this paper problematises Africa's development experience in order to understand the impasse that has characterised it. Three major concerns are addressed: first, development is historically examined as a politically violent and oppressive, culturally deterministic and economically exploitative paradigm operating on a flawed logic. Second, it discusses the reconceptualisation of development as a global project in the current era of neoliberal globalisation, and considers why problems of African development cannot be solved within the context of this equally flawed and problematic reformulation. Finally, the paper proposes ways in which development, rather than abandoned, might be reclaimed so as to allow for reformulations of indigenous African alternatives; that is, reformulated and anchored in indigenous conceptions of social provisioning and the individual's position within a community.
\end{abstract}

\section{Résumé}

Elaboré comme préalable à la reformulation alternative du concept de développement, cet article pose la problématique de l'expérience du développement en Afrique dans le but de comprendre l'impasse le caractérisant. Trois grandes préoccupations y sont exposées : en premier lieu, le développement est examiné sur le plan historique en tant que paradigme politique violent et oppresseur, culturellement déterministe et économiquement exploiteur, opérant à partir d'une logique défectueuse. En deuxième lieu, l'auteur y discute de la reconceptualisation du développement en tant que projet planétaire à cette époque actuelle de mondialisation néolibérale et s'interroge sur la question de savoir pourquoi les problèmes de développement ne peuvent être résolus dans le

* York University, Toronto, Canada. 
contexte de cette reformulation également défectueuse de la problématique. Enfin, cette étude propose des moyens de réaménager le développement de manière à permettre des reformulations d'alternatives propres à l'Afrique. L'auteur avance qu'au lieu d'être complètement abandonné, le développement doit être repris et reformulé, et enraciné dans des conceptions endogènes d'action sociale et de position de l'être humain au sein d'une communauté.

\section{Introduction}

The concept of development, both as an intellectual property and practical enterprise, is in crisis. Though diagnosed to be so for some time now, the stark realities and scale of this crisis increasingly became apparent during the Third World debt crisis in the 1980s, a crisis that has continued and has become even more apparent and glaring in the current era of globalisation. Development was the magic word that gave purpose and a sense of mission to Third World leaders of whatever political and ideological persuasion, especially at the dawn of political independence from colonial rule. In Africa for example, it was the word that undergirded the independence struggle and became an organising ethos around which societies were galvanised and through which processes of social transformation leading to the constitution of new societies were imagined. However, fifty years later, that dream, together with the promise that it represented, has remained largely unfulfilled, as an empty promise, an elusive quest, as Jonathan Crush (1995: 3) calls it. Wolfgang Sachs has pointedly captured this elusiveness in the following words:

Today, the lighthouse [of development] shows cracks and is starting to crumble. The idea of development stands like a ruin in the intellectual landscape. Delusion and disappointment, failures and crimes have been the steady companions of development and they tell a common story: it did not work. Moreover, the historical conditions which catapulted the idea into prominence have vanished: development has become outdated. But above all, the hopes and desires which made the idea fly, are now exhausted: development has grown obsolete (Sachs 1992: 1).

In retrospect, development, especially in its problematic form discussed below, was perhaps never really a useful concept for the productive organisation of human society, nor was it a concept around which the processes and practices of socioeconomic transformation and human emancipation in the so-called Third World, especially Africa, could be imagined, constructed and realised. As such, it is highly problematic to continue insisting on development, especially in its historical and current problematic form 'as the harbinger of human emancipation' (Tucker 1999: 1). This is so because the world 
is replete with practical examples and implications of its failures and unattainability.

The main preoccupations of this paper are three-fold. First, it seeks to historically evaluate the implications of the concept of development on social reproduction in Africa and to interrogate the nature and forms of African development in order to understand the impasse that has characterised development processes on the continent. Second, it aims to demonstrate how the reconceptualisation of development as a global, private sector-led project will not lead to any qualitative change in the impasse of African development. Finally, this paper will seek to identify ways in which development might be reclaimed in order to allow for reformulations of indigenous African alternatives. In that sense, this paper is intended as a preparatory for developing alternative African reformulations of development, both as a theoretical construct and a practical enterprise. It seeks to propose a clarification of the possibilities for a reconceptualisation of development that promotes the embedding of processes and practises of social transformation on the continent in the lived social realities of the region and its people.

\section{Mapping the contours of development}

Development has variously been described as a 'social myth' (Tucker 1999) and an 'elusive concept'(Crush 1995: 3). Historically, development has functioned as a mechanism for socioeconomic control, and politically, as an elitist project and practice of control, domination and exercise of power. As Crush points out, development is a powerful language which has historically functioned as a tool to reorder space, imagine and transform societies, rewrite socioeconomic and political landscapes and replace one reality with another. It has also functioned as the language through which people are constructed as projects to be acted upon, and placed in wretched categories needing the 'redemptive' power of modernity (Crush 1995).

Though theories of development date back to the nineteenth century and development itself was explicitly instituted as a political project in the postSecond World War era, its historical roots originated in earlier European thought: the Enlightenment conception of 'progress' and the Promethean self-conception of European civilisation (McMichael 2004: 286). Europe's self-righteous over-glorification owing to its emergence as the world's leading capitalist power led to the unreflective comparison of their civilisation with others they had succeeded in dominating. This process in turn produced 'a particularistic conception of modernity that they [Europeans] universalised as human destiny'(ibid, emphasis in original). As a language and practice of conceptualising social transformation, development was instituted as a 
political project when the United States, under Harry S. Truman's presidency, decided to make it a key aspect of its global vision in 1949.

Emerging as the dominant power out of the Second World War, the United States envisioned a world in its own image. The world would be united under US leadership: the ideology of One Worldism, initiated by President Franklin D. Roosevelt, would allow for the reconstruction of the economies of Europe and Japan devastated by the war. Politically, it would find expression in the United Nations as a unifying entity, while its economic dimensions would be handled by the Bretton Woods institutions. The intensification of the Cold War between the US-led Western bloc and the Soviet-led Eastern bloc, however, clouded this American imperial vision and led to the redefinition of the concept to Free Worldism and development under Harry Truman. This, in the words of McMichael,

... marked the rise of a US-centred world economy in which American governments deployed military and economy largesse to secure and expand an informal empire as [formal] colonialism receded. With the West's focus now on containing Soviet and Chinese power, the development project settled on the twin foundations of freedom of enterprise and the US dollar as the international currency. In this arrangement, bilateral disbursements of dollars wove together the principal national economies of the West and Japan. As a source of these dollars, the US Federal Reserve System led those countries' central banks in regulating an international monetary system (McMichael 2004: 74).

This process took place, inter alia, within the context of the Cold War ideological battles between the West and the East. Under such conditions, Truman, according to Jan Nederveen Pieterse, instituted the development project as a mechanism to fight the spread of communism which the US portrayed, in the words of Catherine Caufield, as a 'false philosophy which has made such headway throughout the world, misleading many peoples and adding to their sorrows and their difficulties' (Caufield 1996, cited in Nustad 201: 480-81). The United States, whose founding fathers had constructed it as an ethical, ideological, economic and political 'beacon on the hill', found an opportunity, in the words of Sachs, to give worldwide dimensions to their mission through discourses of development and modernisation (Sachs 1992: 1). These discourses informed the assumptions of modernisation theories in the postwar period. Modernisation expected the Third World to live through the mirror image of the United States and the West. This was what the United States, in fact Western development assistance to the Third World, was intended to achieve in conjunction with the aim of winning allies and forestalling the spread of Soviet influence. As Sachs points out, 'development' was 'the frame of reference for ... [the] mixture of generosity, bribery and oppression which 
has characterised the policies [of the United States and the West] towards the South. [And] for almost half a century, good neighbourliness on the planet was conceived in the light of "development"' (ibid). Since the US constructed itself as the model, it was assumed that the so-called 'underdeveloped areas' could only overcome poverty, attain development and become modern if they mimicked the US and the West. But part of the problematic of this thinking was the underlying cultural deterministic assumption, in the crudest form, that blamed indigenous cultures for the perceived 'backwardness' of 'underdeveloped' societies: modernisation in the so-called Third World had to be achieved through overcoming 'the traditional' understood in Enlightenment terms as not only the opposite of modernity but also as an impediment to 'progress'. This thinking underlay Truman's notion of 'underdeveloped areas' which itself connoted outmoded 'backwardness' that should be overcome through modernisationist development interventions. This was the basis of modernisation theories and approaches to development.

Truman's policy has also been described as a strategy for not only the recolonisation of the ongoing anti-colonial movements at the time, but also as a mechanism for the perpetual colonisation of the imagination of nonWestern societies and an instrument for controlling their social realities (Esteva 1992). In fact, as Esteva points out, by merely pronouncing development interventions as a policy, Truman, immediately defined the reality of and actually 'underdeveloped' a diverse and hitherto heterogeneous group of people around the world, homogenising them by their placement in a narrowly defined category of the 'underdeveloped.' This process in turn, robbed billions of their true identity, and transformed them into 'an inverted mirror of other's reality: a mirror that belittles them and sends them off to the end of the queue' (ibid). In this sense therefore, 'development' should be regarded as 'an invention and strategy produced by the "First World" about the "underdevelopment" of the "Third World ... [and] the primary mechanism through which the Third World has been imagined and [made to] imagine itself, thus marginalising or precluding other ways of seeing or doing' (Escobar 1995a: 212; Escobar 1995b).

The idea of 'developing' the 'underdeveloped areas' of the Third World operated on the same logic of previous Eurocentric cultural imperialist narratives of bringing 'progress' and 'civilisation' to 'primitive' and 'backward' cultures, the crudest form of which found expression in the 'Whiteman's burden'. In this thinking, instrumental rationality was completely essentialised as the justification for human progress (Sardar 1999: 44). The ideal of 'progress' and the dominant discourse surrounding it thus became the operative apparatus of the language of modernity, and also the cultural and political project that justified certain practices while delegitimising others. It sti- 
fled other world views, ways of life, being and knowing and placed an unrealistic expectation on non-Western societies to 'catch-up' with the advanced European economic models. It also encouraged the reification of crude economistic and bland mechanistic conceptions of 'progress' which valued economic logic over other indigenous socioeconomic practices as well as cultural and environmental concerns.

Development however, it should be pointed out, is not only about Western exercise of power over the Third World. It is also a political property and controlling instrument of the Third World states and their ruling elites who have arrogated the responsibility of developing societies to themselves. As Frederick Cooper and Randall Packard point out, African and Asian leaders 'positioned themselves to broker relationships among diverse societies, world markets, and international organisations' (Cooper and Packard 1997: 9). The development discourse was not therefore only about how language is used to justify Western exploitation and control of non-Western societies, nor was it only about Western subordination of non-Western societies and belief systems, it was also about the complicity of Third World elites in that very process of Western exploitation and domination and in the violence which accompanied the cultural imposition that employs the language of development. The often uncritical consumption, absorption and somewhat whole-scale internalisation of Eurocentric ideas of progress, social and economic organisations by Third World elites, have very much been part of the crimes and tragedies of development in the Third World. Eurocentrism, as Ziauddin Sardar rightly points out,

... is not simply out there - in the West. It is also in here - in the non-West. As a concept and worldview, the West has colonised the intellectuals in nonEuropean societies. Eurocentrism is thus just as rampant and deep in nonWestern societies as in Europe and the USA: intellectuals, academics, writers, thinkers, novelists, politicians and decision-makers in Asia, Africa and Latin America use the West, almost instinctively, as the standard for judgement and as the yardstick for measuring the social and political progress of their own societies (1999: 44).

These leaders are therefore implicated or complicit in the uncritical promotion of Eurocentric ideas and in the perpetuation of cultural violence against their own people. Indeed the reproduction of Eurocentrism or Westernism, be it wittingly or unwittingly, has therefore also been a non-Western practice, as the non-West 'colludes in its own victimisation as well as in maintaining the global system of inequality' (Sardar 1999: 44). The processes of subordination and domination therefore have to be understood in diffused contexts: from the North and within the North, to the South but also within the South. Similarly, and perhaps more importantly, the unmasking of South- 
ern complicity in the power relations that reproduces its own victimisation should be central to quests for understanding not only development failure in the Third World, but also attempts at seeking alternative reformulations.

\section{Africa and the elusive quest for development}

\section{'Now you look me with a scorn, [when] you eat up all my corn'. - Bob Marley, 'Crazy Baldheads'}

In Africa, the quest for development which accompanied the struggle for political independence, and which continued to dominate the organising ideals of post-independence African societies proved problematic in paradigmatic ways. First, embedded in the concepts and practices of development was the promotion of Westernisation and the privileging of Eurocentric concepts, approaches and models over possible African or other non-Western alternatives. Development was originally packaged as part of the practice and process of transforming and rescuing African societies, which had been constructed as 'backward' and 'primitive' by European colonialists, from their 'primitivity' and 'backwardness,' through modernisation, technological advancement, economic growth and Westernisation. This became, and has remained, the main focus, practise and conceptualisation of development in Africa.

Although there were alternative problematics of and approaches to addressing questions of social transformation and advancement especially in the Third World in general, those concepts and approaches operated on a teleological basis, couched in conceptual languages that privileged and equated development with European progressivism: the end product of any development effort, it was assumed, must be Western-type modernity, economic advancement, and industrialisation. For example, although African states, through the Third World movement, frequently questioned and at times even challenged the legitimacy and dominance of the West in global economic affairs, and the left's critique - seen in the Marxist, dependencia and world systems approaches of the standard modernisation discourses of development - provided alternative conceptions for examining questions of global inequality, exploitation and 'underdevelopment', but they, without question, still accepted this European model of modernisation as foundational, and sought in vain to replicate it in the South (Tucker 1999; Duffield 2001: 22-30).

African elites were especially complicit in this project. They did not seek to thoroughly problematise the Eurocentric foundations of development, or seek to understand that the language of development understood along such clearly Eurocentric lines was in itself implicated in the process of domination of, and the cultural violence that had been inflicted on indigenous social 
life and cultures. African statesmen like Senegal's negritude leader, Leopold Sedar Senghor, or Ghana's pan-Africanist champion, Kwame Nkrumah, as 'Africanist' as they were, still held conceptions of socialism and ideas of organising society influenced by Eurocentric conceptions of progress and modernity. Scientific socialism (itself an alternative modernisation approach but of a socialist type) for example, was accepted as an alternative approach that would allow the development of egalitarian societies in Africa, but that quest would be pursued and thought of in 'rational' economistic and Eurocentric terms. Despite the talk of Africanism, and the need for a synthesis of Western and African cultures and ways of life, development in Africa, to a very large extent, in practice, was simply equated to Westernisation and the vulgarisation (or the misrepresentation and confusion at best) of indigenous social life, traditions and cultures. Julius Nyerere's experiment with 'African socialism', for example, is a case in point. Ujamaa was supposed to be a humanist African socialist project, conceived of with the best intentions, yet it ended up being a failure partly because its claims to 'Africanism' were somewhat imbued with Eurocentric and Western conceptions of progress.

Second, the context within which development interventions took place, created the conditions for failure. Development was a function of asymmetrical power relations between 'rich' and powerful Western states and 'development' agencies like the World Bank on the one hand, and 'poor' and weak neo-colonial African states on the other. It served as a mechanism for the operation of neo-colonialism and a tool for winning Cold War allies in the region. Development aid was not neutral in these power relations: it was an instrument for the projection of the foreign policy objectives of the donor countries on the continent. Within the context of the Cold War and the clientelist politics which developed out of it, political rationality gained precedence over the socioeconomic needs of targeted populations. ${ }^{1}$ Most of the aid therefore ended up going to Cold-War client regimes, no matter how corrupt and authoritarian they were.

However, even within this context, development assistance ended up benefiting the donor countries more than it did the recipients: it created jobs for their nationals, opened up avenues for the exporting of their world views to the continent and promoted the sale of their products and equipment, etc. In most cases, the bulk of the development assistance was spent on administration (for example, salaries of foreign expatriates), and what was considered technical like planning and surveys, rather than on the actual implementation of the earmarked projects. Quite frequently, the donor countries, through their 'experts' who supervised development projects, were not only ignorant about social conditions and local cultures in the targeted countries, but in 
fact held certain abstract conceptions of modernist progress and how it could be achieved. Outcomes would be assumed and the processes through which they were achieved decided upon well before the actual interventions took place. As a result, development interventions, more often than not, became predicated, not on local social conditions and the lived realities of the targeted populations, but on some abstract and a priori conceptions of progress far removed from local realities. The arrogance of foreign governments and their experts in thinking that they knew what was best for African states and the communities in whose lives they intervened, created the condition for failure. It placed enormous constraints on local actors as they grappled with the restrictions imposed on them by the donor states and the development agencies providing the assistance. Development aid was therefore often times self-serving.

Third, and illustrating the abstract and a priori conception referred to above, development was conceptualised only in 'rational' economistic terms. It privileged economic growth and the logic of the market over social provisioning and indigenous cultural, environmental and societal concerns. The excessive attention which was given to the presupposed transition from one extremity (underdevelopment), as V. Y. Mudimbe calls it, to the other (development), was not only highly misleading but it also created the condition for failure (Mubimbe 1988: 4). In fact, the placing of an unnecessary emphasis on formulating techniques of economic change tended to neglect the very structural impediments embedded in the colonial state. These structural weaknesses and defects were inherited by the emerging African state, some of which could not easily be overcome within the contexts of the asymmetrical global material conditions and power relations which underpinned Africa's relations with the West. Development therefore became reductionist, discriminating and deterministic. Anything that did not fall within what was considered rational economic activity mediated by Western conceptions of political economy was considered irrelevant. Thus, in accounting for productive economic activities for example, 'Women, assigned to household [or who worked in the fields], would not be counted, and indigenous peasants, nomads, and forest dwellers could be marginalized or displaced as unproductive' (McMichael 2004). This reductionism then subjugated the fortunes, ways of life and the processes of social provisioning of whole population groups and communities to the logic of the economy, or the market, a process that also determined their social standing and economic well-being (ibid). Economic determinism which stressed the rendering of the environment to economic pursuits placed enormous pressures on the fragile eco-system resulting in a cumulative deterioration of the physical environment as pressures for industrial development, urbanisation, mechanisation of agriculture, 
and infrastructural development like road building, led to environmental degradation, erosion, drought, famine and desertification (ibid: 281). It also excluded and further marginalised already excluded groups (for example, women, the elderly etc.) and imposed an alien model which affected social cohesion.

Fourth, the language of development provided a convenient excuse for the political elites to stifle dissent, pillage the national treasury and slide into authoritarianism. Development was defined as a national public sector project, and it fell under the purview of African governments as their avowed mission. It energised these leaders and gave them a sense of mission and purpose. It was the responsibility of the African governments to imagine new societies and transform old ones. However, framing quests for development in such a language also gave power to these governments to define, control and discipline their populations. Everywhere in Africa, development was used as a self-interested and coercive instrument for political control. More often than not, the allocation of economic resources and the provisioning of social services would be determined, not by necessity and need, but by political expediency and greed. Recalcitrant populations, that is, those perceived as not supporting the government of the day (for example, supporters of the political opposition), would be punished and disciplined by being deprived of government funding for necessary projects and access to essential social amenities, while populations or communities deemed as amenable to supporting the governing party would be rewarded, even if the earmarked projects sometimes proved utterly useless because of the unsuitability of their location. In fact, in most African countries, the language of development provided the leverage for descent into authoritarianism and one party dictatorship.

The argument behind the adoption of one party states in Africa was the logic that there was a need for newly independent states to channel the creative energies of their citizens and utilise them in national development which was deemed, as problematic as it was, as the primary purpose of the state, and to which every political party aspired, rather than wasting that energy by engaging in the divisive politics that came with multi-party systems, divisions that would affect the realisation of development goals. What this meant in practice was the foreclosure of alternative avenues for questioning dominant political and social formations. It also meant frowning on dissent and a descent to authoritarianism. The 'almighty' Kwame Nkrumah for example, was impatient with anybody who did not share his vision for Ghana, and this led him to become increasingly dictatorial towards the end of his reign. It is in this sense that development becomes a handmaiden to power with the discourse surrounding it serving the interests of the powerful (ibid: 284). 
The problematic nature of African development derives partly from the foreignness of the concept, its practice, its exploitative, its oppressive and its particular political form, which has allowed first the West, and then African elites, to define social relations and phenomena on the continent, and dominate other alternatives practices like indigenous understandings of social provisioning, economic relations and ecological conservation. Africa was not 'underdeveloped' or 'poor' before Europe defined it as thus. As Escobar points out, its people did not even always see themselves as 'underdeveloped' (Escobar 1995a: 213). Similarly, there were various clear indigenous understandings of the environment and methods of ecological conservation. Yet, today, Africa is not only a land of unimaginable poverty and 'underdevelopment', but is also the site of increasing environmental degradation and distress.

These definitions themselves, which now form the standard litany of discourses of African political economy, derive from two major sources, a material process that expropriates, in conjunction with a discursive practice that defines. These two processes should not however be considered as separate moments but rather as mutually reinforcing processes intertwined in a deep complicit relationship which perpetuates both exploitation and discursive and representational violence against Africa. As Jonathan Crush points out, it is important to understand that the discourse of development 'is [in fact] constituted and reproduced within a set of material relationships, activities, and powers' (Crush 1995: 6). Centuries of European or Western expropriation and exploitation of the resources of the continent has bred conditions of underdevelopment and incidents of dispossession. It has also stunted possibilities for social transformation, and engendered high levels of violence against indigenous populations both in psychological and physical forms. But perhaps more importantly, the discourses which emanated out of these material relations cemented the asymmetrical power relations. The power of the Western world to define material and social relations, realities, conditions and phenomena, has allowed them to construct, define and understand the non-West (especially Africa) in a particular way.

The power of the West, as Sardar points out, is not only located in its economic muscle and technological might, but also in its power to define. The West defines what is and what is not. All the non-Western world is left with is to either accept these definitions or find itself being defined out of existence (Sardar 1999: 44). For example, 'underdevelopment' as a condition of the South only acquired real discursive salience and became a part of the modernising language after President Harry Truman of the US presented it as the cornerstone of his policy (Gustavo Esteva 1992: 7). Soon afterwards, it became the clarion call for African nationalists like Julius Nyerere 
and Kwame Nkrumah, who insisted on their right to not only rule themselves but to also 'develop' their societies.

Recognising the complicity of knowledge in power relations is very important in understanding the language surrounding the narratives of 'underdevelopment' in Africa. It shows how discursive practices, underlined by unequal material relations, have enabled the West to expropriate African resources, engineer conditions of 'underdevelopment,' define and construct African societies using concepts deeply etched in Eurocentric world views, and have created conditions for the internalisation of these categories by African elites in particular, regardless of political or ideological persuasions. This is a classical situation of, to paraphrase Bob Marley, treating someone with scorn after eating all their corn. Little wonder that Africa's experience with development was and has continued to be disappointing and the continent continues to wallow in poverty and 'underdevelopment'.

\section{Problems of marginality and the intermediate space}

Development failure in Africa is, moreover, in part, a result of marginality, which V. Y. Mudimbe has sought to understand and explain as a condition brought about by schizophrenic pairing of two or more dissimilar and unequal systems, ways of life, institutional practices and world views. This pairing was engineered by colonialism; a condition that has created an intermediate space between indigenous African traditions and European modernity, but to neither of which that intermediate space belongs (Mudimbe 1988: 4). It is in this diffused and intermediate space, situated between the definitional extremes of underdevelopment and development, the traditional and the modern, Mudimbe maintains, that social and economic events come to define the extent of marginality (ibid). This intermediate space illustrates the problems of underdevelopment by revealing

... the strong tension between a modernity that often is an illusion of development, and a tradition that sometimes reflects a poor image of itself. It also unveils the empirical evidence of this tension by showing concrete examples of development failures such as demographic imbalance, extraordinary high birth rates, progressive disintegration of classic family structure, illiteracy, severe social and economic disparities, dictatorial regimes functioning under the cathartic name of democracy, the breakdown of religious traditions, the constitution of syncretic churches, etc. (ibid: 5).

But marginality is also a result of the power of the narratives of modernity to delegitimise and disrupt indigenous processes and replace them (at least at the formal state-centric level) with modernist economistic conceptions privileging a new division of labour which depends on transnational economic flows and international markets (ibid: 4). This process of disruption 
was, and continues to be maintained, by a sustained attack on, and the progressive destruction of, indigenous processes of economic production and social reproduction in areas such as agriculture, textile production and crafts. The quest for modernity initiated by colonialism and pursued in the postindependence era led to the destabilisation of indigenous customary organisations through the incoherent establishment of new social arrangements and institutions. Thus, demographic imbalances between the urban and rural areas due to a massive rural-urban migration and the growing of an urban proletariat, unemployed and marginalised urban youths, etc., are all markers of development failures, conditions that further reinforce marginality (ibid). Any call therefore, for reassessing programmes of modernity in Africa, must accordingly begin with understanding and unravelling this intermediate space, because it "has been a great problem since the beginning of the colonising experience; rather than being a step in the imagined "evolutionary process", it has been the locus of paradoxes that called into question the modalities and implications of modernisation in Africa' (ibid: 5). These problems have made Africa's experience with the forms of development pursued disappointing and the impact of that disappointment for both society and ecology has been disastrous.

\section{Globalisation and African development}

When the crisis of the development paradigm became apparent in the 1980s, following the so-called Third World debt crisis, another discourse emerged. The decline, in the 1970s and 1980s, of the Third World as a 'homogenous' geographical bloc, and of Third Worldism as a powerful pressure group representing the concerns of Third World countries in global political and economic issues, coincided with a paradigm shift in the major Western capitalist countries and this made the deployment of a new language for conceptualising social transformation possible. ${ }^{2}$ In much of the Third World, especially in Africa, the optimism which had surrounded the quest for development had given way to despair and disillusionment at the painful realisation that development was an illusory commodity. This period also coincided with the decline of the Soviet bloc and with it, that of socialism. These shifts engineered major economic restructurings in the major Western capitalist states and initiated processes of global structural transformation, now called globalisation. The discourses which developed out of these conditions were intended as a mechanism for the continued domination and control of the imagination of the non-Western world, which in turn allows for the continued exploitation of these societies and the control of their destinies.

The discourse of development was radically altered in line with this new thinking referred to above. Development, which had previously been thought 
of as a state-managed industrialisation project, operating on the logic and strategy of mechanisation of agriculture and the construction of nationally protected markets, aided by both private sector investment and foreign development aid, was now redefined as a private sector-led global project operating on the logic of free trade and open markets. In the words of Phillip McMichael, development pursued through economic nationalism and protectionism, "came to be viewed as limiting ... because it obstructed the transnational mobility of goods, money and firms, in the service of efficient allocation of global resources' (McMichael 2004: 152). But this clearly represented a self-interested argument by big business in the major industrialised capitalist countries.

The implementation of economic restructuring which targeted economic nationalistic arrangements and which involved the radical alteration and limitation, if not complete elimination, of government intervention both in the operation of the market and development processes, now came to be viewed not only as desirable but also as the only hope for the 'underdeveloped' world to remedy development failure, fight poverty and achieve economic growth and development. Development would therefore become a global project driven by market mechanisms and processes managed by powerful multilateral institutions like the World Bank, the International Monetary Fund (IMF), and the World Trade Organization (WTO). Discourses that privileged market rules, as dictated by neo-classical economic principles, and constitutionalised through neo-liberal governance mechanisms, would underpin these processes and would be implemented through economic restructurings that focused on trade liberalisation, deregulation of the financial markets, and the privatisation of state-owned enterprises (Gill 1995). Transnational corporations would be privileged in this new arrangement, so also foreign investment and exports would lead the drive for growth.

The imposition of these ahistorical policy prescriptions in the form of Structural Adjustment Programmes (SAPs) following the Third World debt crisis in the mid-1980s, marked the official beginning of the implementation of this global project as a new development strategy for African countries. SAP would extend to the region the process of economic restructuring taking hold of Western societies. But SAP was never entirely about development: it was, in part, an aspect of wider crisis displacement strategy and debt management mechanism that had been put in place as a means of shifting the burden of capitalist over-accumulation in the Western countries onto poor vulnerable states in the Global South and to ensure that these debtor countries honoured their debt. But the powerful discourses deployed in the service of this new strategy, coupled with the enormous coercive material power 
of the West, forced these hapless states into implementing Washington's prescribed policies.

For Africa, the origins of these debts themselves were not at all entirely innocent. They were accumulated through both dubious practices and by fraudulent and unjustified means. The quest for development is one of the culprits implicated in Africa's debt crisis and economic burden. Development operates on a logic that perpetuates a vicious circle of exploitation, violence, domination and subordination. Colonialism had instituted truncated national economies in Africa which were by themselves unviable, mostly operating on one-sided specialised commodities, a condition of marginality. But the Eurocentric progressivist logic and economic determinism which underpinned development brought with it certain demands and expectations and placed an unnecessary pressure on these states to 'catch-up' with the West, using resources which were not even there in the first place. The elites who had uncritically internalised this logic, and had proclaimed it as their mission and purpose, resorted to loans to finance development projects when, especially in areas of infrastructure and technology, their economies were unable to sustain the financing of these projects. Most of these loans were however borrowed by corrupt and undemocratic regimes for poorly conceived projects that more often than not proved to be white elephants at best. In fact, in most instances, most of the funds even ended up in the pockets of corrupt government officials who were self-appointed intermediaries of the development process.

A combination of corrupt leadership, and buying into the flawed logic of development not only led to failure, but it also bankrupted the state. Bankruptcy left these states with no other choice but to resort to more loans. Massive borrowing to offset balance of payment problems and to pay off the initial loans borrowed for the financing of development projects pushed these states deeper and deeper into debt and penury. Debt became a self perpetuating vicious circle and tied a yoke round the neck of the ordinary African. In this sense, the uncritical internalisation of the logic of the development paradigm and the way it was pursued, in part, led Africa into the debt trap from which there seems to be no means of escape.

Debt was also a result of the manipulation of Western governments, especially the United States, as it sought to regain its dominance in global finance (Gowan 1999; see Wai 2005). President Nixon's gamble of a twin strategy of high oil pricing and removal of capital controls in the early 1970s, put in place a new international financial and monetary arrangement centred on the United States as the dominant player, and it 'gave the United States government', in the words of Peter Gowan, 'far more influence over the 
international monetary and financial relations of the world than it had enjoyed under the Bretton Woods rules' (Gowan 1999: 24). This system however operated on the logic of crisis as it 'systematically generates payments and financial crises in the South'. Through these internationally provoked crises, the IMF/WB acquired new roles in the regime as auxiliary players. 'The IMF covers the risks and ensures that the US banks don't lose' since they, the IMF and World Bank, would ensure debt repayment through structural adjustment programmes. Banks in the United States had the right to recycle the so-called petro-dollars accumulated in the Gulf as a result of the oil shocks. This was done through loans to Third World countries facing balance of payment problems induced by the shocks and global financial restructuring in the first place. 'If such financial breakdowns were not a systematic element in the regime, the IMF's role would have been marginal, if not redundant' (ibid: 35). In relation to Africa, even with the initial surge of African debt in the 1970s, real interest rates were negative on dollar-denominated loans (Bond 2003: 21).

The dawn of the African debt crisis actually began when the US Treasury suddenly decided to increase interest rates in line with its monetarist policy in the late 1970s. This was all part of its strategy to regain its dominance in global financial and monetary activities described above. A powerful US Treasury with powers over the World Bank and IMF, forced weaker states into compliance with Washington's preferred economic policies through credit manipulation and debt management practices. SAPs were then packaged and marketed through powerful discursive practices that framed them as not only necessary, but the only logical and desirable means of fighting poverty. The globalisation project was then sloganised through the clever use of epithets like 'the global village', as a way of making people in these states feel included.

Through SAPs the IMF and World Bank opened up African economies to a neo-liberal governance framework dictated and directed by them. This included trade liberalisation, privatisation of state-owned enterprises and corporations and the deregulation of capital controls. With SAP, economic 'rationality', in the name of efficiency, took precedence over social needs and provisioning. With the rolling back of government spending in such vital areas as health care, food, education, transport and the elimination of subsidies on agriculture, the real ghost of the new development paradigm promoted by the IMF and World Bank was revealed: SAP was not a development strategy, but a mechanism for domination and economic exploitation. In Africa, their claim to promoting development was a farce. The tale of African misery after over two decades of SAPs would illustrate this fact. Both in academic and policy making circles, there is a general agreement 
that SAPs have failed miserably in Africa, in most cases leaving the countries worse off than they were before their commencement. Development pursued through the globalisation project, has proven to be equally unrealistic and unrealisable. It has not brought the economic prosperity that its proponents had promised, what it has left in its wake instead is misery and further impoverishment of the continent. Ankie Hoogvelt captures this sad and gloomy picture:

... Africa's primary commodities trade has collapsed [since the 1970s], from just over 7 percent of world trade to less than 0.5 percent in the $1990 \mathrm{~s}$. Its share of manufacturing trade never really got a chance to lift off and went down from an already puny 1.2 percent in 1970 to 0.4 percent in 1990 s. The exclusionary logic of the present globalised world order is most dramatically attested in foreign direct investment (FDI) flows. Africa's share of all FDI flows to developing countries has dropped from 13 percent in 1980 to less than 5 percent in the late 1990s. Private (non-public guaranteed) finance now contributes less than a tenth of the resource flows into the continent, the rest being made up of various forms of aid (Hoogvelt 2001: 173175).

This picture, though disappointing, should not come as a surprise. The global development project, pursued through economic policies dictated from abroad was, in a way, designed to ensure the perpetual subordination of the region and the expropriation of its resources. This is why the debt burden persists and why the region continues to suffer unfair trade practices as the Western industrialised world remains very reluctant to open up its markets to African products. It is also why globalisation has been disastrous for African states (Amin 1999: 67).

Coinciding with the adoption of the globalisation project was Third World advocacy for a New International Economic Order (NIEO). The NIEO, as an alternative global development strategy, was preferred by the South for fighting global inequality and poverty. Its aim was to rectify global economic injustices through global income redistribution and the involuntary transfer of wealth and technology from the Western industrialised countries to the Southern states. Though it had its own problems, the NIEO was deemed by the Southern states as a better strategy for fighting poverty. However, it was flatly rejected by the West. If the West was genuinely interested in fighting poverty and promoting 'development' in the Third World, why, one might ask, was the NIEO rejected by them? The answer to this question might not be hard to find: the Western states are not interested in the development of the South. The globalisation project, as has been pointed out, was in fact not about promoting development in the South as was claimed. It was instituted as a response to problems of over-accumulation and declining profitability 
affecting the major Western capitalist economies (Bond 2003; Harvey 2003). It was therefore a crisis displacement mechanism, intended to shift the burden of over-accumulation onto poor Southern states.

It would be a delusion to expect that the problems of the continent would in fact be solved within a mindset that uncritically privileges Westernisation and accepts reductionism and economic determinism as foundational. Any process, etched in Western conceptions of the market, controlled and dictated by the West with African elites playing the ancillary role, completely disregarding the socioeconomic dynamics and indigenous cultural and institutional practices of the people of the region, would prove very difficult, if not completely impossible to work in Africa. The economic dictates of globalisation as a development language, which has been the operating ethos of most African economies for some time now, we have seen, is just another vicious Western cultural and economic tool of domination and exploitation operating on the modernist logic of progress.

What this process however demonstrates, more than anything else, is the discursive power of the West to define progress. When it served their purpose to define it thus, economic nationalism was good, but, once that logic outlived its usefulness, the 'developing' world was presented with another cleverly defined buzz word, packaged in such a way that made it sound not only attractive but desirable, at least to the globalising elites in the region. ${ }^{3}$ Globalisation in Africa is in that sense an elite conception of modernity serving the interests of the powerful, especially powerful Western states, their huge transnational and multinational corporations and the African globalising elites managing the process in the region. Like the development project, it also promotes a universalism that is etched in a Western localism which privileges a Eurocentric world view over other world views, while at the same time disrupting indigenous processes, institutions and ways of life. The logic which undergirds the globalisation process, should not therefore be regarded as different from the one which dictated and directed the development project. Like the language of development, globalisation is informed by the same logic which, in the words of Samir Amin, 'fatally inspires a gradualist perception of a required evolution through stages; [in which] retarded (or peripheral) capitalist societies have to catch up with the advanced model' (Amin 1999: 54). The telos at the end of both the globalisation and development processes is foundational. It therefore should not be looked at as a different phenomenon occurring in isolation, operating within the orbit of its own logic. It should be firmly placed within the context of modernity and the power relations behind it. 


\section{Rethinking African development: The baby or the bath water?}

The problems associated with development have called into question the utility of using its language to conceptualise processes of social transformation and human emancipation. Discourses and debates about the future of development focus on whether to rehabilitate it or completely abandon it and imagine an entirely different future without it. Wolfgang Sachs, for example, calls for development to be banned (Sachs 1992). Similarly, Arturo Escobar believes that development should be completely thrown away because no amount of rehabilitation will rectify its flawed logic. For him, even the critiques of development have reached an impasse, a situation which does not call for a 'better' way of doing development or even for 'another development.' Instead what is needed, Escobar maintains, is a 'radical imagining of alternative futures', 'alternatives to development,' as he calls it, which accordingly 'requires a theoretical and practical transformation in existing notions of development, modernity and the economy'. A starting point for creating such alternative visions for society, he suggests, is to build upon practices of social movements, especially those in the Third World (Escobar 1995a, 1995b; Sachs 1992; Crush 1995; Hall 1992). For Esteva, the attempt at turning 'traditional men and women into economic men' is, to borrow the words of Samir Amin, 'a reactionary utopia' (Amin 1999: 66), against which political actions should be taken in order to allow for a sociological re-imagining of alternative futures. This is because in Esteva's conception, development is in fact dead; it has evaporated and therefore cannot be rehabilitated (Esteva 1992: 22).

Indeed development does carry with it a heavy historical baggage as a legitimating instrument of violence, domination and control which is sometimes difficult if not impossible to think past. However, as Vincent Tucker points out, buying into the logic of abandoning development because of the weight of its historical baggage would also mean abandoning every other concept that has 'been abused and manipulated for purposes of domination and exploitation' (Tucker 1999: 15). Moreover, pointing out the defects and problematic nature of development does not preclude the fact that a reformulation might be possible which in turn could produce some positive moments in human social life. Granted, development has not been a neutral concept, it has been implicated and complicit in the violence perpetrated by modernist discourses, but so also are democracy, socialism, globalisation, the state, freedom and even human rights compromised concepts. Will calling for abandoning development extend to these concepts as well? If yes what are the practical implications? Is it even possible to abandon every word that has been abused and is complicit in modernist projects and discourses? Will 
modern technology, which has also been implicated in the development project, be abandoned?

It is important to recognise that though it was a condition imagined and produced, the problem of 'underdevelopment' or poverty is now a 'real' and practical challenge in Africa, and has to be engaged with, if the material structures of political and economic domination within which development discourses have been constituted and reproduced are to be denaturalised and transformed. How then do we begin to conceptualise creating conditions for enhancing standards of living of people and improvements in social life in areas like health, communication, education and transport? The tension therefore between recognising the historical baggage of development and its potential for emancipation thus present a conundrum, to which, Bob Sutcliffe suggests a caveat must be sounded: throwing the baby away with the bath water would not serve any purpose other than helping to compound an already bad situation (Sutcliffe 1995). The focus therefore, according to this metaphor, should be on initiating a reconstruction process of the concept and practice of development that would allow for the keeping of the baby while the bath water is thrown away. That is, rescuing development from its defects, its oppressive tendencies and culture of violence which has accompanied it; a rehabilitation process, as Tucker calls it, that would allow for the restoration of development as a humanist practice for social transformation. Indigenous African processes and practices of social provisioning, and the cultural and institutional contexts within which they take place, I believe, have a place and role in that reformulation.

A reconstruction of development in Africa should necessarily begin with seeking an understanding of indigenous conceptions, processes and practices of socioeconomic provisioning. That is, seeking to understand how indigenous cultural conceptions regarding economic and social processes are mediated and negotiated. Such a process should seek to understand social transformation and economic provisioning on the continent as relational and social totalities which involve different aspects of life. A social totality operates on the logic that social, political and economic life are not separate, but co-constitutive and functioning as an integrated whole, produced and reproduced through interaction with, and co-dependent on the environment and nature. In much of Africa, for example, indigenous conceptions of social and economic practice were predicated on local ecological knowledge and understandings of natural life. Human life and nature were thought of as codependent on each other. Nature was not regarded as something to be conquered but as forming an integral part of the very essence of human social life. Such ideas even informed various indigenous community relationships (like farming, hunting, fishing etc.), and cultural practices like religion. 
A stress on the 'indigenous' should not however be equated to notions of 'unanimism', as Paulin Hountondji would call it; that is, the idea that a single unproblematic and uncontested indigenous African attitude exists towards nature, social provisioning and economic life. The danger of buying into a unanimist vision is that it prevents the interrogation of the plural and often conflicting strands in indigenous African perspectives, which in turn can foreclose ways in which we sift through these various and often times conflicting attitudes and perspectives. Similarly, notions of the indigenous should not be seen as the validation or blind acceptance of every cultural practice. Some practices on the continent reproduce and reinforce negative tendencies in society like patriarchy, gender inequality and hierarchized oppression. We should therefore be able to recognise and isolate these practices and seek to go beyond them. For true social transformation and human emancipation to take place in Africa, an isolation and exclusion of practices that keep certain sections of society, for example, women, oppressed, marginalised and excluded, must take place. The focus should be on those cultural practices that allow for the construction of alternative societies based on egalitarian principles. An investigation therefore into how the indigenous functions, negotiates, and relates with nature, and how its processes of socio-economic provisioning operates, would help us understand those cultural institutional practices that would point to alternative futures. Seeking to understand indigenous conceptions and cultural practices would help us determine which practices allow for emancipation and social transformation within the African context and which ones do not. And these ideas must necessarily be the basis of any reformulated concept of development in Africa.

This approach then necessarily means the rejection of the practice of privileging of a single world view and way of life over others. The Eurocentric conception of modernity as a progressive process with a clearly defined telos is not only problematic, but in fact also delusory. The idea that modernity should be pursued through Western prescriptions, because its origins were shaped and determined by European experiences, is false. True, modernity emerged as a specific moment in European history, but it was never a monolithic whole occurring within a single orbit. Its dynamics were influenced by diverse historical and social processes which shaped the European historical experiences. The Enlightenment, in fact, had Afro-Asiatic roots which were obscured once Europe claimed reason and rationality as their own and instituted the construction of Africans and Asians as Others that needed to be 'civilised' (Tucker 1999; Bernal 1987; Bessis 2003). But even putting that argument aside, modernity itself cannot be reduced to, in the words of Tucker, 'a tightly integrated whole' (Tucker 1999: 9). The colonial encounter which utilised the modernist discourse, though characterised by unequal power re- 
lations, was far from being a cultural straitjacket imposed and haplessly absorbed. Rather, it was in fact a dynamic process with contestations and local reactions to its very imposition wherever Europe expanded to. Modernity then took various different forms because of these reactions and contestations. In Africa, for instance, an intermediate space resulted as the realm of modernity (Mudimbe 1988). Given these different expressions of modernity in different places, no single charted course can therefore be imposed and expected to produce the same outcome in different places. As such, understanding the specific context and unique dynamics of these processes in different places should therefore necessarily be central to any reformulation of the development concept. In Africa, for example, investigating the intermediate space, both as a problematic hybridised terrain and as a source of marginality and 'underdevelopment' therefore becomes very important to constructing an alternative conception of development in Africa.

The possibility of interrogating different world views and shifting through their plural and multiple contested categories then becomes very important. Vincent Tucker's call for a plurality of discourses, audiences and terrains, as a way of overcoming the Eurocentric foundationalism of development discourses, therefore not only becomes valid but also very necessary (Tucker 1999: 15). However, the method of instituting dialogue between 'intellectuals' from the West and their counterparts from other cultural contexts, he suggests, can be problematic: it runs the risk of being an elitist project, one that may wittingly or unwittingly, construct people as 'objects' to be acted upon and not subjects that act in their own right. Such an instrumental process would end up disenfranchising the very voices such a dialogue may hope to empower. This takes us back to Escobar's point about using the experiments of social movements in order to imagine alternatives to development. Subaltern voices that have been silenced and constructed as mere hapless objects require space for expression, but intellectual dialogue, though important, is hardly a means of achieving that.

Escobar's suggested alternatives should not, however, be constituted as mutually exclusive with seeking alternative reformulations of development. This is where Escobar's suggestion becomes a little problematic: seeking an alternative can be pursued in conjunction with quests for reformulating development, and presenting these as dichotomous binary processes in opposition to each other is dubious at best. Plurality would allow for the irreducible simultaneous existence and the incorporation of the needs, views, concerns and experiences of grassroots movements, indigenous social groups and their cultural institutional practices and values into practices and processes of development. Plurality should therefore be regarded as a decentring dynamic, involving multiple processes through which social phenomena in different 
cultural contexts are understood and accounted for. Empowering subaltern voices can be attained not only through multiplicity of discourses and plurality of terrains or centres (Chakrabarty 2000), but also, and more importantly, through basing processes of social transformation on their lived social realities. A decentring process would allow for multiplicity of perspectives, ways of life, worldviews, experiences, rationalities and practices, instead of just one static model with an in-built logic of progressivism.

Though its recommended solutions for solving the problems of development failure in Africa carry its own problems, the Commission for Africa, for example, recognised the need for such multiplicity of world views in development discourses, especially in relation to Africa:

Ask the big question 'What is development for?', and you get very different answers in different cultures. Many in the developed world see it as being about places like Africa 'catching up'. Development is often described as about increasing choice for individuals. In Africa, by contrast, you might be told that it is something to do with well-being, happiness and membership of a community. An understanding of the cultures of Africa shows that development means putting a greater emphasis on increasing human dignity within a community (The Commission for Africa Report 2005: 121).

This takes us to the important question of the purpose of development itself. How is development understood by those that are the target of development interventions? Is it a state of being (for example well-being, happiness, community membership), or a stated objective (an intended consequence or a predicted outcome at the end of a teleological process)? In much of Africa for instance, the community is given primacy over the individual and it is the individual's position within the community that determines her/his personhood. It is the community that 'defines the person as person, not some isolated static quality of rationality, will, or memory', as is the case with Eurocentric conceptions of liberal individualism (Menkiti 1984: 171). Personhood therefore is acquired, derived from and secondary to the community. Development, according to this idea then is more of a state of being, than a stated objective or abstract idea about catching-up. It is inscribed on the very daily practices of communities and the processes through which they seek happiness and well-being.

Ideas about social transformation and quests for human emancipation and dignity in Africa must be based on the lived social realities of the people who are targets of that transformation. These accordingly should be placed at the heart of the search for alternative reformulations of development. There should be thorough interrogations of these practices and processes, so that they are properly understood and placed within their proper historical, social, political and cultural institutional contexts. A practice that should be 
guarded against is developing abstract conceptions, be they of development or proposed alternative futures without it, which have no practical relevance to commonsensical notions and realities of ordinary social life. Specific understandings of indigenous African social practices and how they affect well-being are therefore necessary building blocks for the reformulation of development.

\section{Conclusions}

The aim of the paper has been two-fold: first, to problematise the language and practice of development in Africa by illustrating its political, violent and contested nature; second, to suggest a way in which a reconstruction of development might be possible. The paper did not set out to provide concrete solutions, either as a corrective or alternative to development, but to set the stage for an African reformulation or reconceptualisation of the concept. In that sense, this paper is a preparatory work for a future reformulation of development from an African perspective. One thing that has been stressed throughout this paper is that programmes designed for promoting human emancipation, based on problematic conceptions as highlighted in this paper, are bound to fail.

Development is a loaded word. It comes with the tensions and baggage of history, a fact that needs to be recognised in any attempt at reformulation. However, it is also equally important to point out that whatever alternatives that come out of the debate about the future of development are bound to carry with them some problems. The question about the possibility of imagining a world where development is no longer possible is necessary to consider here. Can social transformation and human emancipation be conceived of and practiced in concrete terms without considering development? One would suspect not, since even abandoning development completely and constructing alternatives to it would mean engaging in conscious political acts that set out on other courses that construct development as their opposite. That very fact, involves consciously thinking about development, recognising its power and seeking to go beyond it. But even in practical terms, an increasingly 'globalised' world constitutes a real challenge to any rethinking of development and any attempt at framing an alternative that constructs development as its opposite.

External forces and the process of exoticising and packaging difference as economic enterprise (for example, tourism or eco-tourism), have in many ways constituted a problem in achieving this since they have succeeded in insinuating interpolations into cultures and societies that hitherto were insulated from external 'modernist' influences and within that relational vortex, it has been impossible to keep the language of development at bay. These 
processes have instigated comparisons, and through that, consciousness of material differences in comparison to other ways of life. They have further instigated not only the calling into question of hitherto naturally accepted conditions, but also the scrutiny of one's own natural way of life. Questions on whether it is even possible or practical to keep societies insulated from external forces and processes also become important. Are such processes possible, or even necessary? Perhaps the only way of dealing with such external forces is by negotiating an accommodation through pluralistic discourses, processes and practices. Development then should be processes and practices of change and social transformation, a change, thought of not in rational economic, technocratic and instrumentalist terms, but through multiple processes and practices of negotiations, contestations, adaptations and accommodations.

\section{Notes}

1. In the 1980s, the Doe regime of Liberia received almost half a billion dollars from the US in development aid because Doe was a key US ally. Doe, a brutal and corrupt dictator started his reign by publicly executing members of the Tolbert regime he had overthrown in a bloody coup in 1980. See Herbert Howe, 'ECOMOG and Regional Peacekeeping: Lessons from Liberia', International Security, Vol. 21, Issues 3, (Winter 1996/97), pp. 145-177.

2. Though Third Worldism never achieved ideological coherence and clarity, or achieved the organisational consistency of international socialism to which it pretended, it however was a powerful voice that was consistent in articulating the concerns of the Third World and sought to challenge both the dominance and legitimacy of the Western world in global political economy (Duffield 2001: 22).

3. It needs to be pointed out here that globalisation is a fiercely contested process, especially from below, in most parts of Africa. In West Africa, for example, it is leading to incidents of social violence, as the dispossessed and marginalised sections of a globalising region negotiate their exclusion, dispossession and marginalisation. It should not therefore be taken that globalisation and dispossession are haplessly absorbed categories from which there is no escape. See Zubairu Wai (2005).

\section{References}

Amin, Samir, 1999, 'Regionalisation in Response to Polarising Globalisation', in Bjorn Hettne, Andreas, Inotai and Osvaldo Sunkel, eds., Globalism and the New Globalisation, New York: St Mary's Press and UNU/WIDER.

Bernal, Martin, 1987, Black Athena: The Afroasiatic Roots of Classical Civilisations, London: Vintage Books.

Bessis, Sophie, 2003, Western Supremacy: The Triumph of an Idea?, Translated by Patrick Camiller, London: Zed Books. 
Bond, Patrick, 2003, Against Global Apartheid: South Africa Meets the World Bank, IMF and International Finance, 2nd Edition, London: Zed Books.

Caufield, Catherine, 1996, Masters of Illusion: The World Bank and the Poverty of Nations, New York: Henry Holt.

Chakrabarty, Dipish, 2000, Provincialising Europe, Postcolonial Thought and Historical Difference, Princeton, NJ: Princeton University Press.

The Commission for Africa Report, March 2005, London and Addis Ababa p. 121

Cooper, Frederick and Randall Packard, eds., 1997, International Development and the Social Sciences: Essays on the History and Politics of Knowledge, Berkeley, Los Angeles: University of California Press.

Crush, Jonathan, 1995, 'Introduction: Imagining Development', in Jonathan Crush, ed., Power of Development, New York: Routledge.

Crush, Jonathan, ed., 1995, Power of Development, London: Routledge.

Duffield, Mark, 2001, Global Governance and the New Wars: The Merging of Development and Security, London and New York: Zed Books.

Escobar, Arturo, 1995a, 'Imagining A Post-Development Era', in Jonathan Crush, ed., Power of Development, London: Routledge.

Escobar, Arturo, 1995b, Encountering Development: The Making and Unmaking of the Third World, Princeton: Princeton University Press.

Esteva, Gustavo, 1992, 'Development', in Wolfgang Sachs, ed., The Development Dictionary: A Guide to Knowledge as Power, Johannesburg: Witwatersrand University Press.

Gill, Stephen, 1995, 'Constitutionalising Inequality and the Clash of Globalisations’, Millennium, Vol. 23, No. 3, pp. 399-423.

Gowan, Peter, 1999, The Global Gamble: Washington's Faustian Bid for World Domination, London: Verso.

Hall, Stuart, 1992, 'The West and the Rest: Discourse and Power', in Stuart Hall and Bram Gieben, Formations of Modernity, London: Polity, pp. 276-320.

Harvey, David, 2003, 'The New Imperialism: Accumulation by Dispossession', in Leo Panitch and Colins Leys, eds., Socialist Register 2004: New Imperial Challenge, London: Merlin Press.

Hoogvelt, Ankie, 2001, Globalisation and the Postcolonial World, The New Political Economy of Development, Baltimore, Maryland: The John Hopkins University Press.

McMichael, Philip, 2004, Development and Social Change: A Global Perspective, 2nd and 3rd editions, Thousand Oaks, CA: Pine Forge Press.

Menkiti, Ifeanyi A., 1984, 'Person and Community in African Traditional Thought', in Richard A. Wright, ed., African Philosophy: An Introduction, Maryland: Lanham.

Moore, David, and Gerald J. Schmitz, eds., 1995, Debating Development Discourse: Institutional and Popular Perspectives, Basingstoke: Macmillan.

Mudimbe, V. Y., 1988, The Invention of Africa, Gnosis, Philosophy and the Order of Knowledge, Bloomington and Indianapolis: Indiana University Press. 
Nederveen Pieterse, Jan, 2001, Development Theory: Deconstructions/ Reconstructions, London: Sage.

Nederveen Pieterse, Jan, 2000, 'After Post-Development', Third World Quarterly, Vol. 21, No. 2, pp. 175-191.

Nederveen Pieterse, Jan, 1991, 'Dilemmas of Development Discourse: the Crisis of Developmentalism and the Comparative Method', Development and Change, Vol. 22, No. 1, pp. 5-29.

Nustad, Knut G., 2001, 'Development: The Devil We Know?', Third World Quarterly, Vol. 22, No. 4, pp. 479-489.

Sachs, Wolfgang, 1992, 'Introduction', in Wolfgang Sachs, ed., The Development Dictionary: A Guide to Knowledge as Power, Johannesburg: Witwatersrand University Press.

Sachs, Wolfgang, ed., 1992, The Development Dictionary. A Guide to Knowledge as Power, London: Zed Books.

Sardar, Ziauddin, 1999, 'Development and the Location of Eurocentrism', in Ronaldo Munck and Denis O’Hearn, eds., Critical Development Theory: Contributions to a New Paradigm, London: Zed Books.

Sutcliffe, Bob, 1995, 'Development after Ecology', in V. Bhaskar and A. Glyn, eds., The North, the South and the Environment: Ecological Constraints and the Global Economy, New York: St Martin's Press.

Tucker, Vincent, 1999, 'The Myth of Development: A Critique of a Eurocentric Discourse', in Ronaldo Munck and Denis O'Hearn, eds., Critical Development Theory: Contributions to a New Paradigm, London: Zed Books.

Wai, Zubairu, 2005, 'Globalisation and Social Reproduction in West Africa: Hierarchies or Inclusion and Exclusion', Paper Presented at the GSN/ CODESRIA Second Globalisation Conference, Dakar, Senegal, August 2931 . 
